Savunma Bilimleri Dergisi

The Journal of Defense Sciences

Kasim/Nov 2017, Cilt/Volume 16, Sayi/Issue 2.

ISSN (Bas111) : 1303-6831 ISSN (Online): 2148-1776

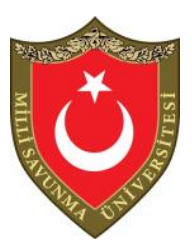

\title{
Kişi Örgüt Uyumunun Örgütsel Adalet Algısı ve Örgütsel Bağlıık İlişkisinde Aracılık Rolü ${ }^{1}$
}

\author{
Kemal KÖKSAL ${ }^{2}$
}

\begin{abstract}
$\ddot{O} z$
Bu çalışmada örgütsel bă̆lllı̆̆ın yaratılmasında etkili olan değişkenlerden örgütsel adalet algisının ve kişi örgüt uyumunun rolü incelenmiştir. Araştırma bir kamu kurumunda çalışan 213 kişiden kolayda örnekleme yöntemiyle toplanan verilerin analizi ile gerçekleştirilmiştir. Ölçekleri doğrulamak için doğrulayıcı faktör analizi, hipotezlerin testi için ise korelasyon ve regresyon analizi yapılmıştır. Analiz sonucunda, örgütsel adalet algısının ve kişi örgüt uyumunun örgütsel bağlllığl anlamlı bir şekilde yordadığl ve örgütsel adalet algısı ve örgütsel bă̆lllık arasındaki ilişkide kişi örgüt uyumunun tam aracılık etkisinin olduğu tespit edilmiştir.

Anahtar Kelimeler: Kişi Örgüt Uyumu, Dăgıtım Adaleti, Örgütsel Bă̆lllık, Örgütsel Adalet. \section{Relationship Between Organizational Justice and Organizational Commitment}

The Mediating Role of Person-Organization Fit on the
\end{abstract}

\begin{abstract}
In this study, the role of organizational justice perception and person organization fit in the formation of organizational commitment has been examined. This study has been carried out with the analyze of the data collected from 213 participants at a public organization by using the convenience sample method. Confirmatory factor analysis was used to confirm the scales and correlation and regression analysis was used to test the hypotheses. As a result of the analysis, it has been found that

\footnotetext{
1 Çalışmanın geniş özeti 4. Örgütsel Davranış Kongresinde bildiri olarak sunulmuştur.

${ }^{2}$ Öğretim görevlisi, MSÜ Kara Harp Okulu, kkoksal@kho.edu.tr
} 
organizational justice perception and person organization fit have a significant effect on organizational commitment and person organization fit has a mediation effect on this relationship.

Keywords: Person Organization Fit, Distributive justice, Organizational Commitment, Organizational Justice.

\section{Giriş}

Örgütsel bağlılık, çalışanların örgütte kalıp kalmama kararını içeren davranışsal veya örgütleriyle olan ilişkisini belirleyen psikolojik bir durumdur (Meyer ve Allen, 1991). Çalışanların örgüte olan bağlılıkları, iş tatmini (Wang, 2015), işten ayrılma davranışı ve niyeti, devamsızlık, çalışan performans1, örgütsel vatandaşlık davranışı, stres ve iş aile çatışması gibi örgütsel değişkenlere karşı tutum ve davranışlarını etkilemektedir (Meyer vd., 2002). Örgütsel bağlılık bu öneminden dolayı birçok araştırmanın konusunu oluşturmaktadır (Devece vd., 2016). Örgütsel bağlılığın oluşmasında ise çalışanın yaşı, cinsiyeti, tecrübesi, eğitimi gibi demografik faktörlerin yanında örgütsel destek, liderlik, rol belirsizliği ve rol çatışması gibi örgütsel değişkenler de etkili olabilmektedir (Meyer vd., 2002). Örgütsel bağlılığın oluşmasında etkili olan bir diğer örgütsel değişken de örgütsel adalet algısıdır (Moorman, 1991; Folger ve Konovsky, 1989). Örgütsel adalet algısı çalışanların ceza ve ödül gibi örgütsel sonuçların dağıtımının, bu dağıtım kararlarındaki sürecin ve insanlar arasındaki etkileşimin nasıl olması gerektiğine yönelik algılarıdır (Bies ve Tripp, 1995). Adalet algısı bireyin çevresini kontrol etme, ait olma, öz sayg1 ve anlamlı kılma ihtiyaçlarından dolayı birey için önemlidir (Cropanzano vd., 2001). Örgütsel adalet algısı konusunda yapılan çalışmalar, iş tatmini, güven, örgütsel vatandaşlık davranışı, işten ayrılma niyeti, çalışan performans1 ve örgütsel bağlılık gibi çeşitli örgütsel değişkenlerle olan ilişkisini göstermektedir (Colquitt vd., 2001). Genel olarak çalışanlar, yeteneklerini en iyi şekilde kullanabilecekleri bir örgütte çalışma eğilimindedir. Çalışanın nerede çalışacağına karar vermesinde önemli bir faktör olan kişi örgüt uyumu, kişi ve örgütün öznitelikleri, değer yargıları ve amaçları arasındaki uyum ile kişinin karakteristik özellikleri ve örgüt değerleri arasındaki benzeşim olarak tanımlanabilir (Kristof-Brown, 1996). Kişi örgüt uyumu çalışanların işe ve örgüte karşı olan tutum ve davranışlarını etkilemektedir. Yapılan çalışmalarda kişi örgüt uyumu ile örgütsel bağl1lık (Chatman, 1991; Ahmadi vd., 2014) ve örgütsel adalet 
Kişi Örgüt Uyumunun Örgütsel Adalet Algısı ve Örgütsel Bağlllık İlişkisinde Aracılık Rolü

algısı arasında anlamlı ilişkiler olduğu gösterilmiştir (Tikanmaki, 2001; Heponiemi vd., 2011). Kişi örgüt uyumu ve örgütsel adalet algısı arasındaki ilişkiyi inceleyen çalışmaların ise az sayıda olduğu görülmektedir. Bireylerin örgütlerde çalışması sadece para kazanma ihtiyacı ile açıklanmamaktadır. Bireyler örgütlere dâhil olarak değer ve kimlik duygularını da karşılamaktadır (Lind ve Tyler, 1988). Çalışanların örgütlerinde gördükleri adil davranış, onlara örgütle ilişkisi hakkında ipucu vermektedir (Cropanzano vd., 2001).

Çalışanların örgütsel bağlılığını etkileyen unsurların anlaşılabilmesi amacıyla, yukarıdaki kuramsal açıklamalardan yola çıkarak, örgütsel adalet algısının örgütsel bağlılıkla ilişkisi ve bu ilişkide kişi örgüt uyumunun nasıl bir rol üstlendiğinin ortaya konulması, araştırma sorunsalını oluşturmaktadır. Yöneticiler tarafından örgütsel bağlılığı etkileyen unsurların daha iyi anlaşılması, performans, örgütsel vatandaşlık davranışı, işten ayrılma niyeti ve davranışı gibi çeşitli örgütsel davranışların daha iyi yönetilmesine imkân sağlayabilecektir.

\section{Kuramsal Çerçeve}

\section{Örgütsel Bağlılık}

Örgütsel bağlılık kavramı çok sayıda araştırmanın konusu olmuş ve çalışanlarda bağlılık yaratmak insan kaynakları yönetiminin temel amaçları arasında yer almıştır (Meyer vd., 2012). Meyer ve Allen (1991) örgütsel bağlılığı, çalışanların örgütte kalıp kalmama kararını içeren davranışsal veya örgütleriyle olan ilişkisini belirleyen psikolojik bir durum olarak tanımlamaktadır. Ayrıca örgütsel bağlılık konusunda yapılan tanımlar incelendiğinde kavramın davranışsal ve tutumsal bakış açısına göre farklı tanımlandığını ifade etmişlerdir (Meyer ve Allen, 1991). Kavrama davranışsal yaklaşan çalışmalar, bireyde tutum değişikliği yaratan davranışlara odaklanırken (O'Reilly ve Caldwell, 1981), tutumsal yaklaşımlar, bağlılık yaratan durumları ortaya koymakta ve bu bağlılığın davranışsal sonuçları ile ilgilenmektedir (Steers, 1977). Örgütsel bağlılık kavramının çeşitli bakış açılarına bağlı olarak farklı şekillerde sınıflandırıldığı görülmektedir. Zaman içerisinde örgütsel bağlılığın farklı yazarlarca çıkara dayalı, yabancılaştırıcı ve ahlaki bağlılık (Etzioni, 1961); devam, kenetlenme ve kontrol bağlılığı (Kanter, 1968); uyum, özdeşleşme ve içselleştirme bağlılığı (O'Reilly ve Chatman, 1986); duygusal, devam ve 
normatif bağlılık (Meyer ve Allen, 1991) olarak sinıflandırıldığ görülmektedir. $\mathrm{Bu}$ araştırma kapsamında örgütsel bağlılık, tutumsal ve davranışsal ayrıma dayanılarak (Mowday vd., 1982), çalışanın örgüte yönelik tutumu şeklinde genel bir kavram olarak değerlendirilmiştir.

Çalışanların örgüte olan bağlılığını sağlamak günümüzde tüm örgütler için performans ve başarıyı sağlamak adına oldukça önemlidir. Örgütsel bağlılık, çalışan devir oranında düşüş, motivasyonda artış, örgütsel vatandaşlık davranışında ve örgütsel destek algısında artış gibi çeşitli örgütsel sonuçlara neden olmaktadır. Örgütsel bağlılığın düşük olduğu durumlarda ise işten kaytarmalar ve aykırı işyeri davranışında artış görülebilmektedir (Morrow, 2011; Meyer vd., 2002). Morrow (2011) örgütsel bağl1lığın bu öneminden dolayı, iyi yönetilebilmesi için, örgütsel bağlılığı etkileyen unsurların iyi anlaşılması gerektiğini ifade etmiştir. Yapılan çalışmalar incelendiğinde, örgütsel bağlılığ 1 etkileyen unsurların kişilik özellikleri, demografik, örgütsel ve çevresel faktörler olarak sınıflandırıldığ görülmektedir (Hanaysha, 2016; Gonzalez ve Guillen, 2007; Meyer vd., 2002). Örgütsel destek algısı, liderlik, rol belirsizliği, örgütsel adalet, sosyalizasyon süreci, eğitim ve ücretlendirme, performans değerlendirme sistemi, çalışma arkadaşları, kişisel amaçların desteklenmesi gibi örgütsel değişkenlerin örgütsel bağlılığın oluşmasında etkili olduğu yapılan çalışmalarla gösterilmiştir (Morrow, 2011).

\section{Örgütsel Adalet}

Örgütsel adalet algısı uzun yıllardan beri araştırmacılar tarafından incelenen bir konu olmuştur. Yapılan çalışmalar, çalışanların adalete ilişkin algılarının, onların işe yönelik tutum ve davranışlarını biçimlendirdiğini göstermektedir (Colquitt vd., 2001; Greenberg, 1990; Colquitt vd., 2013). Bireyler için örgütsel adalet algısı kendi çıkarlarını maksimize etmek (araçsal) ve grup içindeki yerlerini gösterdiği için (ilişkisel) önemlidir (Lind ve Tyler, 1988). Örgütsel adalet konusunda yapılan çalışmalar genelde dağıtım adaleti, prosedür adaleti ve etkileşim adaleti (Greenberg, 1987; Cropanzano vd., 2001) olmak üzere üç boyutlu yapıyı doğrularken, bazı çalışmalarda dağıtım ve prosedür adaletine kişilerarası ve bilgisel adalet eklenmiştir (Colquitt vd., 2001). Bunların dışında örgütsel adalet algısını genel bir boyut olarak ele alan çalışmalar da söz konusudur (Ambrose ve Schminke, 2009; Holtz ve Harold, 2009). Dağıtım adaleti algısı, bireylerin örgütlere yaptıkları yatırımlarla elde ettiği sonuçları karşılaştırdığında 
Kişi Örgüt Uyumunun Örgütsel Adalet Alglsı ve Örgütsel Bağlılık İlişkisinde Aracılık Rolü

oluşmaktadır. Bireyler kendi katkıları ve bunun sonucunda elde ettikleri kazanımlarını, diğerlerinin katkı ve kazançlarıyla kıyaslayarak dağıtım adaleti algılarını şekillendirirler (Folger ve Cropanzano, 1998). Dağıtım adaletinin temelinde Homans'1n (1961) Sosyal Mübadele ve Adams'ın (1965) Eşitlik Kuramı vardır. Dağıtım adaleti algısı daha çok ücret ve ödüller gibi maddi kazanımlar tarafindan etkilenmekte (McFarlin ve Sweeney, 1992) ve çalışanların duygu (öfke, mutluluk, gurur, suçluluk vb.; (Weiss vd., 1999)), düşünce (başkaları ya da kendi katkı/çıktıları hakkındaki düşünceleri; (Adams, 1965)) ve davranışlarını (performans, örgütsel vatandaşlık, işten ayrılma vb.; (Colquitt vd., 2013)) etkilemektedir. Çalışanlarda adaletsizlik algısı oluştuğunda örgütsel bağlılıkları, performansları ve örgütsel vatandaşlık davranışları azalmaktadır (Ambrose, 2002). Örgütsel adalete ilişkin olumlu algılar ise özellikle iş tatminini ve örgütsel bağl1lığı etkilemektedir (Simpson ve Kaminski, 2007; Folger ve Konovsky, 1989; McFarlin ve Sweeney, 1992). Farklı ülkelerde yapılan çok sayıda araştırma ile örgütsel adaletin örgütsel bağlılığı etkilediği gösterilmiştir (Ulukap1 vd., 2014; Akgündüz ve Güzel, 2014; Selvitopu ve Şahin, 2013; Bağc1, 2013; Iş1k, Uğurluoğlu ve Akbolat, 2012; Bal, 2014; Yazıcıoğlu ve Topaloğlu, 2009; Rahman vd., 2016; Ooi vd., 2014; Gim ve Desa, 2014). Yukarıdaki kuramsal açıklamalardan ve yapılan çalışmalardan yola çıkarak araştırmanın birinci hipotezi oluşturulmuştur.

Hipotez 1: Dağıtım adaletinin örgütsel bağlllık üzerinde etkisi vardır.

\section{Kişi Örgüt Uyumu}

Kişi örgüt uyumu, örgütsel sonuçlarla olan ilişkisinden dolayı son yıllarda araştırmacı ve yöneticilerin ilgisini çeken bir konu olmuştur (Ahmadi vd., 2014). Kristof-Brown (1996), birey ve örgüt arasında, en azından bir tarafın diğer tarafın beklentilerini karşıladığında ya da temel değerleri paylaştığında kişi örgüt uyumundan söz edilebileceğini ifade etmektedir. Kişi örgüt uyumunun temelleri Schneider'ın (1987) geliştirmiş olduğu çekim-seçim-yıpranma (attraction-selection-attrition) teorisine dayanmaktadır. Teoriye göre birey, örgüt ikliminin, değerlerinin ve normlarının, kişiliğine ve değerlerine uyması durumunda örgütü ilgi çekici bulmaktadır. Seçim aşamasında ise örgüt, bireyi, örgütün kültürüne, değerlerine ve normlarına uygun bulmaktadır. Yıpranma ise kişi örgüt 
uyumunun algılanmaması durumunda, bireyin örgüte yönelik olumsuz tutum ve davranış geliştirmesidir. Kişi örgüt uyumunun olması durumunda ise bireylerin örgütsel vatandaşl1k, iş tatmini gibi olumlu iş tutum ve davranışları sergileyebileceği ifade edilebilir (Arthur vd., 2006). Örgütün kültürü ve değerlerini benzer bulan ve o örgüte çekilen bireylerin bir arada olması, örgütün homojenliğini artırmakta ve örgütteki bireylerin tipini belirlemektedir (Schneider, 2001). Örgütün bütünü göz önüne alındığında, örgütün geri kalan norm ve beklentilerine yönelik bireyin uyumu sosyalizasyon süreci ile gerçekleşmektedir (Cable ve Parsons, 2001). Örgütü ile uyum içinde olan birey, daha fazla iş tatmini, örgütsel bağlllık ve işe devam etme gibi olumlu iş tutumları sergilemektedir (Verquer vd., 2003). Kişi örgüt uyumu ile olumlu iş tutumları arasındaki ilişki, teorik olarak, uyumun, bireyin ihtiyaçlarını karşılama fırsatı doğurması (Rounds vd., 1987) ve bireyin kendi değerleriyle benzer olan çalışma arkadaşlarıyla, daha fazla iletişime geçerek, inanç, değer ve davranışlarını güçlendirmesi ile açıklanmaktadır (Swann vd., 1992). İlgili literatür incelendiğinde, kişi örgüt uyumu ile örgütsel bağlılık ilişkisini inceleyen çok sayıda araştırma olduğu fakat örgütsel adalet ve kişi örgüt uyumu arasındaki ilişkiyi araştıran çalışmaların az olduğu görülmektedir (Hofman ve Woehr, 2006; Verquer vd., 2003; Kristof-Brown vd., 2005). Lind ve Tyler (1988) tarafindan geliştirilen İlişkisel Modele göre çalışanlar kendilerine adil davranıldığını gördüğünde, kendilerine değer verildiğini düşünmektedirler. Bu düşünce de kişi örgüt uyumunu artırabilmektedir (He vd., 2014).

Sosyo-Ekololojik kurama (Bronfenbrenner, 1977) göre bireylerin davranışlarını etkileyen alt sistemler söz konusudur. Çok sayıda değişkenden oluşan alt sistemlerin etkileşimi sonucunda bireyin davranışları şekillenmektedir (Tudge vd., 2011). Bu kapsamda dağıtım adaleti algısı, bireylerin kişi örgüt uyumu algısını etkilemekte, oluşan kişi örgüt uyumu algısı da örgütsel bağl1lığı etkilemektedir. Diğer bir ifade ile dağıtım adaleti algıs1 ve örgütsel bağlılık arasındaki ilişki bireylerin kişi örgüt uyumuna ilişkin algısı aracılığı ile gerçekleşmektedir. Kuramsal açıklamalardan ve yapılan çalışmalardan yola çıkarak araştırmanın ikinci hipotezi oluşturulmuştur.

Hipotez 2: Kişi örgüt uyumunun, dağıtım adaleti ve örgütsel bağlılık arasındaki ilişkide aracılık etkisi vardır.

$\mathrm{Bu}$ çerçevede oluşturulan araştırma modeli Şekil 1'dedir. 


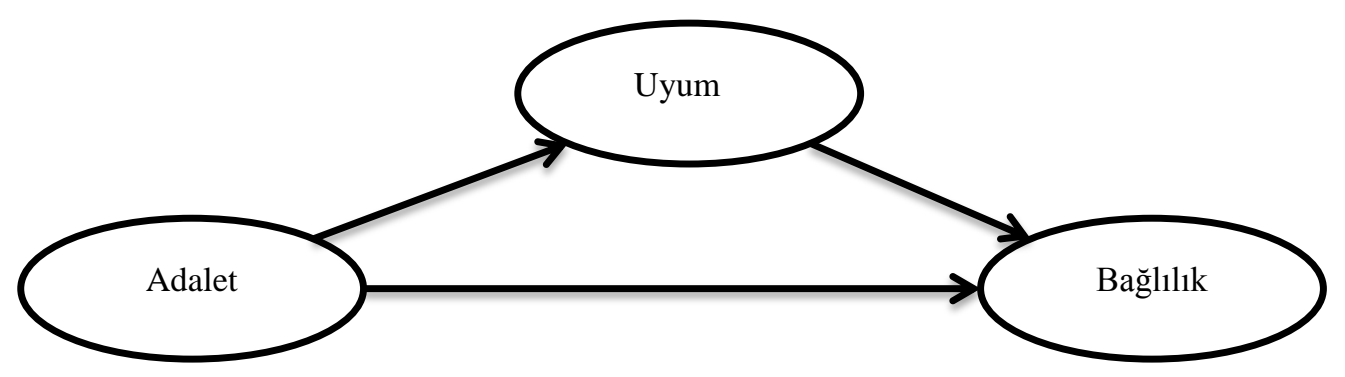

Şekil 1: Araştırma Modeli

Yöntem

Yöntem başlığı altında araştırmanın örneklemi, araştırmada kullanılan ölçekler, analizler ve bulgular başlıklarına yer verilecektir.

\section{Örneklem}

Araştırmanın örneklemini, kamu kurumunda çalışan ve kolayda örnekleme yöntemiyle seçilen 213 kişi oluşturmaktadır. Katılımcıların \%63'ü bayan, \%37'si ise erkek, \%48'i evli, \%52'si bekârdır. Örneklemde yer alanların \%12,3'ü doktora, \%32'si yüksek lisans mezunu, \%55,7'si lisans mezunudur. Katılımcıların yaşlarının dağılım aralıkları ise 22-28 yaş $\% 35,8,29-34$ yaş $\% 28,9,35-40$ yaş $\% 17,3,41-46$ yaş $\% 16,47$ ve üstü olanlar ise $\% 2$ 'dir.

\section{Ölçekler}

Örgütsel bağl1lık, Jaworski ve Kohli (1993) tarafindan geliştirilen ölçek kullanılarak ölçülmüştür. Ölçeğin Türkçeye uyarlaması Şeşen (2010) tarafından yapılmıştır. Ölçek toplam 6 maddeden oluşmaktadır. Kişi örgüt uyumu Edward (1991) tarafından geliştirilen ve Valentine vd. (2002) tarafından revize edilen beş sorudan oluşan tek boyutlu kişi örgüt uyumu ölçeği ile ölçülmüştür. Dağıtım adaleti algısı Moorman'un (1991) üç boyutlu adalet ölçeğinin dağıtım adaleti boyutu kullanılarak ölçülmüştür. Dağıtım adaleti boyutu beş ifadeden oluşmaktadır. Ölçeklerin geçerliliği iç tutarlılık ve doğrulayıcı faktör analizi ile test edilmiştir. Bağlılık ölçeğinin iç 
tutarlılığg 0,854 ; kişi örgüt uyumu ölçeğinin iç tutarlılığg 0,874 ; dağıtım adaleti ölçeğinin iç tutarlılığı ise 0,917 olarak bulunmuştur. İç tutarlılık rakamları (Cronbach Alpha) incelendiğinde ölçeklerin güvenilir oldukları değerlendirilmiştir.

Doğrulayıcı faktör analizi (DFA) ile ölçeklerin faktör geçerliliği incelenmiştir. Yapılan DFA sonuçlarına göre örgütsel bağlılık ölçeğinin yap1 geçerliliğini düşüren ifadeler ölçekten çıkartılmıştır. "Gerektiğinde kurumun iyiliği için gönüllü olarak görevlerimin çok ötesinde çalışabilirim" ifadesi ve "İşime bağlılık duymuyorum" ifadesi ölçeğin uyum değerlerini düşürdüğü için ölçekten çıkartılmıştır. Kalan ifadeler için DFA tekrar yapılmış ve ölçeğin iyi uyum gösterdiği görülmüştür (Tablo 1). Kişi-örgüt uyumu ölçeğinin DFA sonuçları incelendiğinde ölçeğin uyumunu azaltan "Kişisel değerlerim, çalıştığım kurumun değerleri ile iyi bir uyum içindedir" ifadesi çıkartılarak, analiz tekrar yapılmış ve ölçeğin dört maddeli yapısının iyi uyum gösterdiği değerlendirilmiştir (Tablo 1). Dağıtım adaleti ölçeğine yapılan DFA sonucunda, yap1 geçerliliğini düşüren "Üstlendiğim sorumluluklar ile aldığım ödüller birbirine uygundur" ifadesi çıkarılarak analiz tekrar edilmiştir. Kalan ifadelere yönelik DFA sonuçlarına göre ölçeğin iyi uyum gösterdiği değerlendirilmiştir (Tablo1).

Tablo1: Tek Boyutlu DFA Sonuçları

\begin{tabular}{lccccccc}
\hline \multicolumn{1}{c}{ Ölçek } & $\chi^{2}$ & sd & $\boldsymbol{\chi}^{2} / \mathbf{s d}$ & $\begin{array}{r}\text { RMSE } \\
\text { A }\end{array}$ & CFI & GFI & AGFI \\
\hline Örgütsel Bağlıık & 0,941 & 2 & 0,471 & 0,000 & 1,000 & 0,998 & 0,988 \\
Kişi Örgüt Uyumu & 8,500 & 3 & 2,833 & 0,097 & 0,981 & 0,979 & 0,930 \\
Örgütsel Adalet & 0,570 & 2 & 0,285 & 0,000 & 1,000 & 0,999 & 0,993 \\
\hline
\end{tabular}

RMSEA: Root Mean Square Error of Approximation (Yaklaşık Hataların Ortalama Karakökü); CFI: Comparative Fit Index (Karşılaştırmalı Uyum Indeksi); GFI:Goodness of Fit Index (İyilik Uyum İndeksi); AGFI: Adjusted Goodness Fit Index (Düzeltilmiş İyilik Uyum İndeksi)

\section{Analiz ve Bulgular}

Veriler, SPSS ve AMOS paket programlanı kullanılarak analiz edilmiştir. Örgütsel adaletin örgütsel bağl1lı̆̆a etkisinde, kişi örgüt uyumunun aracılığına yönelik çalışmadaki hipotezler korelasyon ve regresyon analizi yapılarak test edilmiştir. 
Kişi Örgüt Uyumunun Örgütsel Adalet Alglsı ve Örgütsel Bağlılık İlişkisinde Aracılık Rolü

Örgütsel bağlılık, dağıtım adaleti ve kişi örgüt uyumu değişkenlerinin tanımlayıcı istatistikleri ve korelasyon analizi sonucu Tablo 2 'de gösterilmiştir. Sonuçlar incelendiğinde dağıtım adaleti ve örgütsel bağlılık algılarının ortalamanın altında olduğu, kişi örgüt uyumunun ise ortalamaya yakın olduğu görülmektedir.

Korelasyon sonuçlarına göre dağıtım adaleti algısı ile kişi örgüt uyumu arasında orta seviyede, $(\mathrm{r}=0,638 \mathrm{p}<0,01)$; örgütsel bağl1lıkla orta seviyeye yakın, pozitif bir ilişki vardır $(\mathrm{r}=0,401 \mathrm{p}<0,01)$. Örgütsel bağlılık ile kişi örgüt uyumu arasında da pozitif, orta seviyede bir ilişki söz konusudur $(\mathrm{r}=0,532 \mathrm{p}<0,01)$.

Tablo 2: Ortalama, Standart Sapma ve Korelasyon Analizi Sonuçları

\begin{tabular}{lcccc}
\hline & Ort. & S.S. & Adalet & Uyum \\
\hline Dağıtımı Adaleti & 2,370 & 0,940 & & \\
Kişi Örgüt Uyumu & 3,099 & 0,915 & $0,638^{* *}$ & \\
Örgütsel Bağlılık & $\mathbf{2 , 9 5 1}$ & $\mathbf{0 , 7 8 9}$ & $\mathbf{0 , 4 0 1 * *}$ & $\mathbf{0 , 5 3 2 * *}$ \\
\hline
\end{tabular}

$* \mathrm{p}<0,01$

Hipotezlerin testi regresyon analiziyle gerçekleştirilmiştir. Regresyon analizi (Tablo-3) sonucuna göre, dağıtım adaletinin örgütsel bağl1lığın belirleyicisi olduğu tespit edilmiştir $(\beta=0,408, p<0,00, F=38,427$, $\left.\mathrm{R}^{2}=0,167\right)$. "Dağıtım adaletinin örgütsel bağlılık üzerinde etkisi vardır." şeklindeki birinci hipotez kabul edilmiştir. Araştırmanın ikinci hipotezi "Kişi örgüt uyumunun, dağıtım adaleti ve örgütsel bağlılık arasındaki ilişkide aracılık etkisi vardır." şeklindedir. Aracılık analizinin yapılabilmesi için birtakım şartlar söz konusudur. İlk olarak bağımsız değişken dağıtım adaletinin, bağımlı değişken örgütsel bağl1lık ve aracı değişken kişi örgüt uyumu üzerinde bir etkisi olmalıdır. İkinci olarak aracı değişken kişi örgüt uyumunun bağımlı değişken örgütsel bağlılık üzerinde etkisi olmalıdır. Son olarak kişi örgüt uyumu, dağıtım adaleti ile regresyon modeline dâhil edildiğinde bağımsız değişkenin etkisinin ya kaybolması (tam aracılık) ya da azalması (kısmi aracılık) gereklidir (Baron ve Kenny, 1986). Aracilik analizi sonucunda dağıtım adaletin örgütsel bağlılığa olan etkisinde, kişi örgüt uyumunun tam aracı olduğu tespit edilmiştir. Aracılık etkisinin anlamlı olup olmadığ Sobel testiyle kontrol edilmiştir. Sobel testi, bağımsız değişken tarafından açıklanan varyanstaki azalmanın anlamlılığını ölçmektedir (Sobel, 1982). Sobel testi sonucuna göre arac1lık rolünün 
anlamlı olduğu bulunmuştur (Sobel $\mathrm{z}=5,021 \mathrm{p}<0,00$ ). Araştırmanın iki numaralı hipotezi de desteklenmiştir.

Tablo 3: Regresyon Analizi Sonuçları

\begin{tabular}{|c|c|c|c|c|}
\hline \multicolumn{5}{|c|}{ Bağımlı Değişken: Örgütsel Bağlıık } \\
\hline & $\beta$ & $\mathrm{R} 2$ & t değeri & $p$ değeri \\
\hline Dağıtım Adaleti & 0,408 & 0,167 & 6,199 & ,000 \\
\hline \multicolumn{5}{|c|}{ Bağımlı Değişken: Örgütsel Bağlılık } \\
\hline & $\beta$ & $\mathrm{R} 2$ & t değeri & $p$ değeri \\
\hline Kişi Örgüt Uyumu & 0,525 & 0,275 & 8,543 &, 000 \\
\hline \multicolumn{5}{|c|}{ Bağımlı Değişken: Kişi Örgüt Uyumu } \\
\hline & $\beta$ & $\mathrm{R} 2$ & t değeri & p değeri \\
\hline Dağıtım Adaleti & 0,633 & 0,401 & 11,340 & ,000 \\
\hline \multicolumn{5}{|c|}{ Bağımlı Değişsken: Örgütsel Bağlılık } \\
\hline & $\beta$ & $\mathrm{R} 2$ & t değeri & $\mathrm{p}$ değeri \\
\hline Dağıtım Adaleti & 0,127 & 0,285 & 1,605 & ,110 \\
\hline Kişi Örgüt Uyumu & 0,444 & 0,285 & 5,622 & ,000 \\
\hline
\end{tabular}

\section{Sonuç ve Tartışma}

Çalışanların örgüte olan bağl1lıkları onların iş tatmini, işten ayrılma niyeti, devamsızlık, stres, örgütsel vatandaşlık davranışı gibi birçok değişkeni etkileyen önemli bir konudur (Meyer vd., 2012). Bu araştırmada yöneticiler ve konu ile ilgilenenler için çalışanların örgütsel bağlılıklarını artırabilecek yolların daha iyi anlaşılabilmesi adına örgütsel bağlılığı etkilediği düşünülen dağıtım adaleti algısının (Heponiemi vd., 2011) ve kişi örgüt uyumunun (Ahmadi vd., 2014) etkisi araştırılmıştır. Araştırma sonuçlarına göre dağıtım adaleti algısının örgütsel bağlılığı etkilediği ve bu ilişkide kişi örgüt uyumunun aracılık etkisinin olduğu görülmektedir.

Çalışma bulguları örgütsel bağlılığın anlaşılması için 1şık tutmaktadır ve benzer çalışmaların sonuçlarını destekleyici niteliktedir. Kristof-Brown ve diğ. (2005) tarafından yapılan, kişi örgüt uyumunun sonuçlarını inceledikleri meta analiz çalışmasında kişi örgüt uyumunun örgütsel bağglılı̆̆1 etkilediği gösterilmiştir. Viswesvaran ve Ones (2002) tarafından yapılan, örgütsel adaletin ve alt boyutlarının iş tutum ve davranışlarıyla olan 
Kişi Örgüt Uyumunun Örgütsel Adalet Alglsı ve Örgütsel Bağlılık İlişkisinde Aracılık Rolü

ilişkilerini inceledikleri meta analiz çalışmasında örgütsel adalet algısının bağl1lık üzerindeki etkisi gösterilmiştir.

Dağıtım adaleti algısının örgütsel bağlılığın bir önceli olduğu (McFarlin ve Sweeney, 1992) bu çalışmada da desteklenmiş ayrıca kişi örgüt uyumunun dağıtım adaleti algısının örgütsel bağlılık üzerindeki etkide tam aracı olduğu da gösterilmiştir.

Araştırmanın birtakım kısıtlılıkları bulunmaktadır. Araştırmada sosyal beğenilirlik etkisinin değerlendirilmeye alınmaması ve ortak faktör varyansının dikkate alınmaması bir kısıttır. Örgütsel bağlılığın daha iyi anlaşılması için, yapılacak araştırmalarda, örgütsel bağlılığın diğer öncüllerinin (Morrow, 2011) etkisinin araştırılabileceği değerlendirilmektedir.

\section{Extended Summary}

\section{The Mediating Role of Person-Organization Fit on the Relationship Between Organizational Justice and Organizational Commitment}

\section{Introduction}

Organizational commitment is a behavioral condition involving employees' decision to remain in the organization or psychological condition that determines employees' association with organizations (Meyer and Allen, 1991). Employees' commitment of organization affects attitudes and behaviours towards organizational variences such as; job satisfaction (Wang, 2015), intention to leave, absenteeism, employee performance, organizational citizenship behavior, stress and work-family conflict (Meyer et al., 2002). Due to the importance of organizational commitment, a great deal of research has been done (Devece et al., 2016). Organizational justice perception effects the organizational commitment (Moorman, 1991; Folger and Konovsky, 1989). Organizational justice perception is associated with how organizational outcomes are distributed, which processes are followed and how interaction is done (Bies and Tripp, 1995). Individuals usually want to work in an organization where they can use their talents in the best way. Person-organization fit that is an important factor in deciding where an employee will work has been defined in a number of ways including value 
congruence, goal congruence and the match between employees' needs and the characteristics of the organization (Kristof-Brown, 1996). Personorganization fit effects the attitudes and behaviors of employees. It has been shown that there is a significant relationship between person-organization fit and organizational commitment (Chatman, 1991; Ahmadi et al., 2014) and organizational justice perception (Tikanmaki, 2001, Heponiemi et al., 2011). There are few studies that examine the relationship between personorganization fit and organizational justice. Working in organizations is not only explained by the need to earn money, but it is also explained by the acquisition of identity and value (Lind and Tyler, 1988). The fair treatment gives employees clues about the relationship with the organization (Cropanzano et al., 2001).

To understand the factors affecting organizational commitment, the relationship between distributive justice and organizational commitment and the mediating role of person-organization fit were examined. Understanding organizational commitment can lead to better management of various organizational behaviors such as performance, organizational citizenship behavior, intention to leave.

\section{Theoretical Framework}

\section{Organizational Commitment}

Organizational commitment is a behavioral condition involving employees' decision to remain in the organization or psychological condition that determines employees' association with organizations. Morrow (2011) stated that due to the importance of organizational commitment, the factors affecting organizational commitment must be well understood. Organizational commitment has a positive effect on various organizational outcomes such as turnover, motivation, organizational citizenship behavior and organizational support.

\section{Organizational Justice}

Studies has shown that justice perception of employees affect their work attitudes and behaviors (Colquitt et al., 2001; Greenberg, 1990; Colquitt et al., 2013). The distribution justice perception is formed when employees compare the results of their investments with the others (Folger 
Kişi Örgüt Uyumunun Örgütsel Adalet Alglst ve Örgütsel Bağlllık İlişkisinde Aracilkk Rolü

and Cropanzano, 1998). When employees perceive injustice, organizational commitment, performance of employees, and organizational citizenship behavior are reduced (Ambrose, 2002). Positive perceptions of organizational justice, in particular, affect job satisfaction and organizational commitment (Simpson and Kaminski, 2007; Folger and Konovsky, 1989; McFarlin and Sweeney, 1992). From the above theoretical explanations and from the studies made, the first hypothesis of the research was established. commitment.

Hypothesis 1: Distribution justice has an impact on organizational

\section{Person-Organization Fit}

Person-organization fit has become a subject of interest to researchers and managers in recent years due to its relation to organizational outcomes (Ahmadi et al., 2014). Person-organization fit is based on the attraction-selection-attrition theory developed by Schneider (1987). According to the theory, individual finds organization interesting if values and norms of the organization's climate conform to its personality and values. At the selection phase, the organization finds the individual for values and norms of the organization's climate. If the individual does not perceive person-organization fit, attrition that developing of negative attitudes and behavior to organization may occur. If there is personorganization fit, the individual can show positive job attitudes and behaviors such as organizational citizenship, job satisfaction (Arthur et al., 2006). When the relevant literature is examined, it can be seen that there are a large number of studies examining the relationship between person-organization fit and organizational commitment, but there are few studies investigating the relationship between organizational justice and person-organization fit (Hofman and Woehr, 2006; Verquer et al., 2003; Kristof-Brown et al., 2005).

The perception of distributive justice affects the person-organization fit, and the perception-organization fit affects the organizational commitment. In other words, the relationship between the distributive justice perception and organizational commitment is achieved through the person-organization fit. The second hypothesis has been developed from the theoretical explanations. 
Hypothesis 2: Person-organization fit has a mediating effect on the relationship between perception of distributive justice and organizational commitment.

\section{Method}

\section{Sample}

The sample of the research consisted of 213 people working in the public institution and selected with convenience sampling method. In the sample, $63 \%$ of the participants were female, $37 \%$ were male, $48 \%$ were married and $52 \%$ were single. $12.3 \%$ of the participants in the sample are doctoral, $32 \%$ are masters and $55.7 \%$ are undergraduate.

\section{Instruments}

Organizational commitment was measured using the scale developed by Jaworski and Kohli (1993). Person-organization fit was measured using the scale developed by Edward (1991) and adapted by Valentine et al. (2002). The distributive justice perception was measured using the distributive justice dimension of Moorman's (1991) three-dimensional justice scale. The validity of the scales was tested by internal consistency and confirmatory factor analysis (CFA). When internal consistency statistics (Cronbach Alpha) were examined, it was considered that the scales were reliable. According to the results of the CFA, the two statements that reduce the construct validity of the organizational commitment scale and one statement of the person-organization fit scale were removed from the scales.

\section{Analyze and Findings}

The data were analyzed using SPSS and AMOS packet programs. The hypothesis has been tested by performing correlation and regression analysis.

When the descriptive statistics and correlation analysis results of the organizational commitment, distributive justice and person-organization fit variables are examined, distributive justice and organizational commitment are below the average, and the person-organization fit is closer to the average. 
Kişi Örgüt Uyumunun Örgütsel Adalet Algıss ve Örgütsel Bağlllık İlişkisinde Aracılık Rolü

According to the results of the correlation, between the distributive justice perception and the person organization fit was positive moderate $(\mathrm{r}=$ $0,638 \mathrm{p}<0,01)$; between the distributive justice perception and organizational commitment was positive moderate level $(\mathrm{r}=0.401 \mathrm{p}<0.01)$ relationship. There is also a positive and moderate relationship between organizational commitment and person-organization fit $(\mathrm{r}=0,532 \mathrm{p}<0,01)$.

Hypothesis testing was performed by regression analysis. According to the regression analysis, the perception of distributive justice is determinant of the organizational commitment $(\beta=0.408, p<0,00, F=$ $38,427$, R2 $=0,167)$. So hypothesis 1 was accepted. According to the mediating analyze results, the relationship between the perception of distributive justice and the organizational commitment fully mediated by person-organization fit. So hypothesis 2 was also accepted.

\section{Conclusion and Discussion}

In this study, the effects of the perception of distributive justice and person-organization fit on the organizational commitment has examined. The results have shown that organizational commitment of the employees affected by the perception of distributive justice and person-organization fit has fully mediating effect on this relationship.

The findings of the study shed light on the understanding of organizational commitment and support the results of similar studies. Kristof-Brown et al. (2005), the meta-analysis study, which examines the results of person-organization adjustment, has shown that personorganization fit influences organizational commitment. In the meta-analysis study conducted by Viswesvaran and Ones (2002) has shown that the effects of organizational justice and sub-dimensions on job attitudes and behaviors such as organizational commitment.

The research has some limitations. Social desirability effect and common factor variance have been ignored. For a better understanding of organizational commitment, it is assessed that the effect of other antecedents of organizational commitment (Morrow, 2011) can be investigated. 


\section{Kaynakça}

\section{Kitaplar}

Adams, J. S. (1965). Inequity In Social Exchange. R. Folger, \& R. Cropanzano içinde, Organizational Justice and Human Resources Management (s. 1-4). London: Sage Publications.

Ahmadi, S., Mohammadpour, B., Rajabi, M., \& Baghbani, F. (2014). Effect of Person-Organization Fit on Organizational Commitment. International Journal of Information Technology and Management Studies, 1(1), 33-43.

Akgündüz, Y., \& Güzel, T. (2014). Örgütsel Adalet ile Örgütsel Bağlllık Arasındaki İlişkide Örgütsel Güvenin Aracılık Etkisi,. Anadolu University Journal of Social Sciences, 14(3), 1-18.

Ambrose, M. L. (2002). Contemporary justice research: a new look at familiar questions. Organizational Behavior and Human Decision Processes, 89, 803-812.

Ambrose, M. L., \& Schminke, M. (2009). The role of overall justice judgments in organizational justice research: A test of mediation. Journal of Applied Psychology, 49, 491-500.

Arthur, W., Bell, S. T., Villado, A. J., \& Doverspike, D. (2006). The Use of Person-Organization Fit in Employment Decision Making: An Assessment of Its Criterion-Related Validity. Journal of Applied Psychology, 91(4), 786-801.

Bağc1, Z. (2013). Çalışanların Örgütsel Adalet Algılarının Örgütsel Bağl1lıkları Üzerindeki Etkisi: Tekstil Sektöründe Bir İnceleme. Uluslararası Yönetim İktisat ve İşletme Dergisi, 9(19), 163-184.

Bal, V. (2014). Örgütsel Adalet ve Örgütsel Bağlılık İlişkisi: Manisa'daki Eğitim Kurumlarında Bir Araştırma,. Aksaray Üniversitesi İktisadi İdari Bilimler Fakültesi Dergisi, 6(1), 1-9.

Baron, R. M., \& Kenny, D. A. (1986). The Moderator-Mediator Variable Distinction in Social Psychological Research: Conceptual, Strategic and Statistical Considerations. Journal of Personality and Social Psychology, 51, 1173-1182.

Bies, R. J., \& Tripp, T. M. (1995). The Use and Abuse of Power: Justice as Social Control. R. Cropanzano, \& M. Kacmar içinde, Organizational Politics, Justice, and Support: Managing the Social Climate of Work Organizations (s. 131 -145). New York: Quorum Books. 
Kişi Örgüt Uyumunun Örgütsel Adalet Algıss ve Örgütsel Bağlllık İlişkisinde Aracilkk Rolü

Brinsfield, C. T., Edwards, M. S., \& Greenberg, J. (2009). Voice and silence in organizations: Historical review and current conceptualizations. J. Greenberg, \& M. S. Edwards içinde, Voice and silence in organizations (s. 3-33 ). UK: Emerald.

Bronfenbrenner, U. (1977). Toward an Experimental Ecology of Human Development. American Psychologist, 513-531.

Cable, D., \& Parsons, C. (2001). Socialization tactics and personorganization fit. Personnel Psychology, 54, 1-23.

Chatman, J. (1991). Matching people and organizations: Select and socialization in public accounting firms. Administrative Science Quarterly, 36, 459-484.

Colquitt, J., Conlon, D., Wesson, M., Porter, A., \& Yee Ng, K. (2001). Justice at the Millennium: A Meta-Analytic Review of 25 Years of Organizational Justice Research. Journal of Applied Psychology, 86(3), 425-445.

Colquitt, J., Scott, B. A., Rodell, J. B., Long, D. M., Zapata, C. P., Conlon, D. E., \& Wesson, M. J. (2013). Justice at the millennium, a decade later: A meta-analytic test of social exchange and affect-based perspectives. Journal of Applied Psycholog, 98, 199-236.

Cropanzano, R., Byrne, Z. S., Bobocel, D. R., \& Rupp, D. E. (2001). Moral virtues, fairness heuristics, social entities, and other denizens of organizational justice. Journal of Vocational Behavior, 58, 164-209.

Çakıcı, A. (2010). Örgütlerde İşgören Sessizliği: Neden Sessiz Kalmayı Tercih Ediyoruz?, (1. Baskı b.). Ankara: Detay Yayıncılık.

Demir, M. (2014). İşörenlerin adalet algılamaları kapsamında sessizlik davranışının kariyer beklentisi ile ilişkisi. International Journal of Human Sciences, 11(1), 1095-1113.

Devece, C., Palacios-Marques, D., \& Alguacil, A. P. (2016). Organizational Commitment and Its Effects On Organizational Citizenship Behavior In A High-Unemployment Environment. Journal of Business Research, 69, 1857-1861.

Etzioni, A. (1961). A Comparative Analysis of Complex Organizations, . New York: Free Press.

Folger, R., \& Cropanzano, R. (1998). Organizational Justice and Human Resource Management. USA: Sage Publications Inc. .

Folger, R., \& Konovsky, M. (1989). Effects of Procedural And Distributive Justice On Reactions To Pay Raise Decisions. Academy of Management Journal, 35(1), 115-130. 
Gim, G., \& Desa, N. (2014). The Impact of Distributive Justice, Procedural Justice, and Affective Commitment on Turnover Intention among Public and Private Sector Employees in Malaysia. International Journal of Social Science and Humanity, 4(6), 487-492.

Gonzalez, T. F., \& Guillen, M. (2007). Organizational Commitment: A Proposal for a Wider Ethical Conceptualization of Normative Commitment. Journal of Business Ethics, 78(3), 401-414.

Greenberg, J. (1987). A Taxonomy of Organizational Justice Theories. Academy of Management Review, 12, 9-22.

Greenberg, J. (1990). Organizational justice: yesterday, today and tomorrow. Journal of Management, 16, 399-432.

Hanaysha, J. (2016). Testing the Effects of Employee Engagement, Work Environment, and Organizational Learning on Organizational Commitment. Procedia - Social and Behavioral Sciences, 229, 289 297.

He, H., Zhu, W., \& Zheng, X. (2014). Procedural Justice and Employee Engagement: Roles of Organizational Identification and Moral Identity Centrality. Journal of Business Ethics, 122, 681-695.

Heponiemi, T., Elovainio, M., Kuusio, H., Noro, A., Finne-Soveri, H., \& Sinervo, T. (2011). The effects of ownership, staffing level and organisational justice on nurse commitment, involvement, and satisfaction: A questionnaire study. International Journal of Nursing Studies, 48, 1551-1561.

Hofman, B. J., \& Woehr, D. J. (2006). A quantitative review of the relationship between person-organization fit and behavioral outcomes. Journal of Vocational Behavior, 68, 389-399.

Holtz, B., \& Harold, C. (2009). Fair Today, Fair Tomorrow? A Longitudinal Investigation of Overall Justice Perceptions. Journal of Applied Psychology, 9(5), 1185-1199.

Homans, G. (1961). Social behavior: Its elementary forms. New York: Harcourt Brace \& World.

Iş1k, O., Uğurluoğlu, Ö., \& Akbolat, M. (2012). Sağlik Kuruluşlarında Örgütsel Adalet Algılarının Örgütsel Bağlılığa Etkisi. Doğuş Üniversitesi Dergisi, 13(2), $254-265$.

Jaworski, B., \& Kohli, A. (1993). Market Orientation: Antecedents and Consequences. Journal of Marketing, 57, 52-70.

Kanter, R. (1968). Commitment and Social Organizations. American Sociological Review, 449-517. 
Kişi Örgüt Uyumunun Örgütsel Adalet Algıss ve Örgütsel Bağlllık İlişkisinde Aracilkk Rolü

Kristof-Brown, A. (1996). Person-Organization Fit: An İntegrative Review Of İts Conceptualizations, Measurement And İmplications. Personnel Psychology, 49(1), 1-49.

Kristof-Brown, A. L., Zimmerman, R. D., \& Johnson, E. C. (2005). Consequences of individual' fit at work: A Meta-Analysis of personjob, person-organization, person-group, and person-supervisor fit. Personal Psycholog, 58, 281-342.

Lind, E. A., \& Tyler, T. (1988). The social psychology of procedural justice. New York: Plenum.

Masterson, S. S., K., L., M., G. B., \& S., T. M. (2000). Integrating Justice and Social Exchange: The Differing Effects of Fair Procedures and Treatment on Work Relationships. Academy of Management Journal, 43(4), 730-755.

McFarlin, D., \& Sweeney, P. (1992). Distributive and procedural justice as predictors of satisfaction with personal and organizational outcomes. Academy of Management Journal, 36, 626-637.

Meyer, J. P., \& Allen, N. J. (1991). A Three-Compenent Conceptualization of Organizational Commitment. Human Resource Management Review, 1(1), 61-89.

Meyer, J. P., Stanley, L. J., \& Parfyonova, N. M. (2012). Employee commitment in context: The nature and implication of commitment profiles. Journal of Vocational Behavior, 80, 1-16.

Meyer, J., Stanley, D. J., Herscovitch, L., \& Topolnytsky, L. (2002). Affective, Continuance, and Normative Commitment to the Organization: A Meta-analysis of Antecedents, Correlates, and Consequences. Journal of Vocational Behavior, 61, 20-52.

Milliken, F., Morrison, E., \& Hewlin, P. (2003). An Exploratory Study of Employee Silence:An exploratory study of employee silence : Issues that Employees Don't Communicate Upward and why? Journal of management studies, 40(6), 1453-1476.

Moorman, R. H. (1991). Relationship Between Organizational Justice and Organizational Citizenship Behaviors: Do Fairness Perceptions Influence Employee Citizenship? Journal of Applied Psychology, 76(6), 845-855.

Morrow, P. C. (2011). Managing organizational commitment: Insights from longitudinal research. Journal of Vocational Behavior, 79, 18-35. 
Mowday, R., Porter, 1., \& Steers, R. (1982). Employee Organization Linkages: The Psychology of Commitment, Absenteeism and Turnover. New York: Academic Pres.

Ooi, C. L., Yusof, A., Geok, S. K., \& Omar, Z. (2014). ects of Distributive Justice, Perceived Organisational Support and Intrinsic Motivation on Malaysian Volunteer Coaches' Affective Commitment. MiddleEast Journal of Scientific Research, 19, 153-160.

O'Reilly, C., \& Caldwell, D. (1981). The Commitment and Job Tenure of New Employees: Some Evidence of Postdecisional Justification. Administrative Science Quarterly, 26, 597-616.

O'Reilly, C., \& Chatman, J. (1986). Organizational Commitment and Psychological Attachment: The Effects of Compliance, Identification, and Internalization on Prosocial Behavior. Journal of Applied Psychology, 71, 492-499.

Pinder, C., \& Harlos, K. (2001). Employee Silence: Quiescence and Acquiescence as Responses to Perceived Injustice. Research in Personnel and Human Resources Management, 20, 331-369.

Rahman, A., Shahzad, N., Mustafa, K., Khan, M. F., \& Qurashi, F. (2016). Effects of Organizational Justice on Organizational Commitment. International Journal of Economics and Financial Issues, 6, 188196.

Rounds, J. B., Dawis, R. V., \& Lofquist, L. H. (1987). Measurement of person- environment fit and prediction of satisfaction in the theory of work adjustment. Journal of Vocational Behavior, 31, 297-318.

Schneider, B. (1987). The people make the place. Personnel Psychology, 40, 437-453.

Schneider, B. (2001). Fits about fit. Applied Psychology: An International Review, 50, 141-152.

Selvitopu, A., \& Şahin, H. (2013). Ortaöğretim Öğretmenlerinin Örgütsel Adalet Algıları ile Örgütsel Bağl1lıkları Arasındaki İlişki,. Ahi Evran Üniversitesi Kırşehir Eğitim Fakültesi Dergisi (KEFAD),, 14(2), 171-189.

Simpson, P., \& Kaminski, M. (2007). Gender, organizational justice perceptions, and union organizing. . Employ Respons Rights, 19, 5772.

Sobel, M. (1982). Asymptotic confidence intervals for indirect effects in structural equation models. Sociological Methodology, 13, 290-312. 
Kişi Örgüt Uyumunun Örgütsel Adalet Algıss ve Örgütsel Bağlllık İlişkisinde Aracilkk Rolü

Steers, R. (1977). Antecendents and Outcomes of Organizational Commitment. Administrative Science Quarterly, 22, 46-56.

Swann, W. B., Stein-Seroussi, A., \& Giesler, B. R. (1992). Why people selfverify. Journal of Personality and Social Psychology, 62, 392-401.

Şeşen, H. (2010). Öncülleri ve Sonuçları ile Örgüt İçi Girişimcilik: Türk Savunma Sanayinde Bir Araştırma. Yayınlanmamış Doktora Tezi, Kara Harp Okulu. Ankara: Savunma Bilimleri Enstitüsü.

Tikanmaki, A. K. (2001). The Impact of Person Organization Fit and Perceptions of Justice on Employee Organizational Commitment, Job Satisfaction, and Trust Towards Management After An Acquisition. not printed MBA Thesis. Canada : B.B.A. Helsinki School of Economics and Business Administration.

Tudge, J., Mokrova, I., Karnik, R., \& Hatfield, B. (2011). Uses and misuses of Bronfenbrenner's bioecological theory of human development. Journal of Family Theory \& Review, 1(4), 198-210.

Tulubas, T., \& Celep, C. (2012). Effect of perceived procedural justice on faculty members' silence: the mediating role of trust in supervisor. Social and Behavioral Sciences, 47, 1221 - 1231.

Ulukap1, H., \& Aykut Bedük. (2014). Örgütsel Adaletin İşgörenlerin Örgütsel Bağlllık Düzeylerine Etkisi: Konya'da Bir Araştırma,. Uluslararası Sosyal Araştırmalar Dergisi, 7(31), 771-778.

Van Dyne, L., Ang, S., \& Botero, I. C. (2003). Conceptualizing employee silence as multidimensional constructs. Journal of Management Studies, 40, 1359-1392.

Verquer, M. L., Beehr, T. A., \& Wagner, S. H. (2003). A meta-analysis of relations between person-organization fit and work attitudes. Journal of Vocational Behavior, 63, 473-489.

Verquer, M., Beehr, T., \& Wagner, S. (2003). A meta-analysis of the relations between person- organization fit and work attitudes. Journal of Vocational Behavior, 63, 473-489.

Viswesvaran, C., \& Ones, D. S. (2002). Examining the Construct of Organizational Justice: A Meta-Analytic Evaluation of Relations with Work Attitudes and Behaviors. Journal of Business Ethics, 38(3), 193-203.

Wang, Y. (2015). Examining organizational citizenship behavior of Japanese employees:A multidimensional analysis of the relationship to organizational commitment. International Journal of Human Resource Management, 26(4), 425-444. 
Weiss, H. M., Suckow, K., \& Cropanzano, R. (1999). Effects of justice conditions on discrete emotions. Journal of Applied Psychology, 84, 786-794.

Whiteside, D. B., \& Barclay, L. (2013). Echoes of Silence: Employee Silence as a Mediator Between Overall Justice and Employee Outcomes. Jouranl Bussines Ethics, 116, 251-266.

Yazıcıŏ̆lu, İ., \& Topaloğlu, I. G. (2009). Örgütsel Adalet ve Bağl1lık İlişkisi: Konaklama İşletmelerinde Bir Uygulama,. İşletme Araştırmaları Dergisi, 1(1), 3-16. 